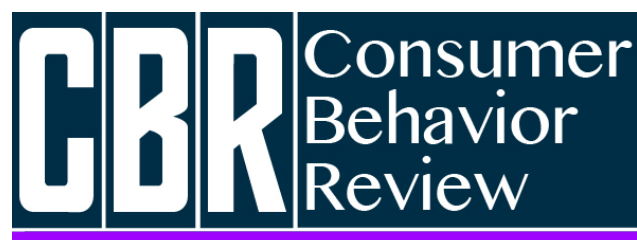

Revista Comportamento do Consumidor
Ajeyalemi, O. F., \& Olarewaju, A. D. (2020). Low Cost Strategy as a Remedial Prescription for Resuscitating Nigeria's Ailing Domestic Airline Industry: The customers' perspective. Consumer Behavior Review, 4(2), 66-83.
ISSN: 2526-7884

Editor: Prof. Dr. Marconi Freitas da Costa Journal's e-mail: cbr@ufpe.br
Evaluation: Double blind review

Received: February 18, 2020

Accepted: April 28, 2020

\title{
LOW COST STRATEGY AS A REMEDIAL PRESCRIPTION FOR RESUSCITATING NIGERIA'S AILING DOMESTIC AIRLINE INDUSTRY: THE CUSTOMERS' PERSPECTIVE
}

\section{Estratégia de baixo custo como receita corretiva para ressuscitar a indústria aérea doméstica da Nigéria: a perspectiva dos clientes}

\author{
Oladipupo Folorunsho Ajeyalemi ${ }^{1}$ \\ ORCID: https://orcid.org/0000-0002-5559-6396 \\ E-mail: oajeyalemi@unilag.edu.ng \\ Adeniyi Damilola Olarewaju² \\ ORCID: https://orcid.org/0000-0001-6156-8634 \\ E-mail: olarewajuadeniyi@yahoo.com
}

\footnotetext{
${ }^{1}$ Accounting and Business Administration, DLI, University of Lagos, Lagos, Nigeria

${ }^{2}$ School of Business, Tecnologico de Monterrey, Monterrey, Mexico
}

\begin{abstract}
The number of domestic airlines operating in the Nigerian aviation industry have been on a steady decline for a number of years. This is despite a gradual increase in the average number of domestic travelers. Reasons adduced for this anomaly is related to high operational costs, debt burden and outstanding financial obligations. This study therefore examined low cost strategy as a prescription for struggling airlines in the Nigerian domestic airline industry. Stated preference theory served as the theoretical
\end{abstract}

\section{Resumo}

O número de companhias aéreas domésticas que operam no setor de aviação nigeriano tem diminuído constantemente há vários anos. Isso ocorre apesar de um aumento gradual no número médio de viajantes domésticos. Os motivos apresentados para essa anomalia estão relacionados a altos custos operacionais, carga de dívida e obrigações financeiras pendentes. Portanto, este estudo examinou a estratégia de baixo custo como receita para as companhias aéreas em dificuldades no setor aéreo doméstico da Nigéria. A teoria da 
framework because it allowed the construction of realistic alternatives that respondents could choose from based on their preferences. The study was conducted in two phases using conjoint analysis. The first phase identified competitive tools relevant to Nigeria while the second phase involved respondents choosing from an orthogonal content analysis matrix based on selected factors and their attribute levels. Results indicated a high internal correlation value between observed and estimated preferences while no significant correlations was observed between the competitive tools, suggesting good model fit. Findings revealed that out of the six competitive tools, Refund policy and In-Flight Menu were the most important to passengers while Channel of ticket purchase was the least important. Based on the computer-generated pathworth utility matrix, the authors suggested a workable low-cost model that airlines could adopt to ensure survival and profitability. Implications are discussed.

Keywords: Airline Industry, Low-Cost Strategy, Competitive Tools, Conjoint Analysis, Customer Preferences preferência declarada serviu de base teórica, pois permitiu a construção de alternativas realistas que os entrevistados pudessem escolher com base em suas preferências. 0 estudo foi realizado em duas fases, utilizando análise conjunta. A primeira fase identificou ferramentas competitivas relevantes para a Nigéria, enquanto a segunda fase envolveu os entrevistados escolhendo uma matriz de análise de conteúdo ortogonal, com base em fatores selecionados e seus níveis de atributos. Os resultados indicaram um alto valor de correlação interna entre preferências observadas e estimadas, enquanto não foram observadas correlações significativas entre as ferramentas competitivas, sugerindo um bom ajuste do modelo. As descobertas revelaram que das seis ferramentas competitivas, a política de reembolso e o menu de bordo eram as mais importantes para os passageiros, enquanto o canal de compra de passagens era o menos importante. Com base na matriz de utilidade gerada por computador, os autores sugeriram um modelo viável de baixo custo que as companhias aéreas poderiam adotar para garantir a sobrevivência e a lucratividade. Implicações são discutidas.

Palavras-chave: Indústria Aérea, Estratégia de Baixo Custo, Ferramentas Competitivas, Análise Conjunta, Preferências do Cliente.

\section{INTRODUCTION}

Air travel is a crucial transportation network across the globe in terms of its importance for global business development and it has been opined that the aviation industry is an important industry to any country's economic growth as it could be an avenue for the provision of direct and indirect jobs, revenue earner and tourism booster (Gibbons \& Wu, 2019; Zhang \& Graham, 2020). In Nigeria, commercial air transportation has witnessed some substantial developments in the recent past (Ukpere, Stephens, Ikeogu, Ibe \& Akpan, 2012). In its annual report, the National Bureau of Statistics (2020) attributed a $19.45 \%$ annual growth rate for passenger air travel between 2017 and 2018. Also, according to Federal Airports Authority of Nigeria \{FAAN\} (2019), passenger traffic which was slightly above three million in 1988 had risen above sixteen million by 2018 and it is projected to grow, under current trends, by $174 \%$ in the next 20 years (International Air Transport Association $\{$ IATA $\}, 2019 a)$. This suggest a steady increase in the number of domestic and international air passengers in Nigeria over the last three decades.

However, it would have been expected that there should be a corresponding increase in the number of domestic airlines and aircrafts operating in the Nigerian airspace. Shockingly, this appears not to be the case as there has been a steady decline in the number of domestic airlines operating in Nigeria. In the 1990s, there were about thirty different airlines available in the domestic routes in Nigeria but as at 2010, only about seven airlines were operating domestic scheduled flights (Olaniyi, 
2015). This decline in number of airlines is in spite of the phenomenal increase in the average number of Nigerian air travelers in the past two decades as domestic airline operators such as Nigerian Airways, Kabo airline, Okada airline, Concord airline, Chanchangi airline and Slok airline have stopped operations for various reasons (Meggison, 2015). Uhuegho, Nwokocha and Olaniyi (2014) posited that one of the major reasons airlines in Nigeria may be struggling is the enormous debt burden they grapple with while the United States Embassy in its 2012 Economic Report linked the frequent financial quagmires in the aviation industry worldwide to losses caused by low fares, high interest rates, and rising fuel costs. This implies that even though sales appear to have increased over the years through increase in passenger traffic, domestic airlines in Nigeria are unable to meet their financial obligations, subsequently resulting in failure.

The few operating airlines in Nigeria are not immune from the myriad of challenges affecting the aviation industry as was evident from the notice of suspension of services from a big player like Aero Contractors that cited inability to achieve operational targets as the reason for temporary business closure. The indefinite suspension of operations commenced on September 1, 2016 and will be until further notice (Aero Contractors, 2016). Barely 24 hours after Aero Contractors airlines announced suspension of its operations, another domestic carrier, First Nation airlines suspended operations as from September 2, 2016, due to operational overhaul (Vanguard, 2016). In the same vein, Nigeria's biggest airline in terms of fleet size, Arik Air suspended operations for 24 hours between Tuesday, September 13 and Wednesday, September 14, 2016 due to its inability to renew its aircraft insurance (This Day, 2016). Curiously, Arik Air and other domestic operators benefited from a 200 Billion Naira government intervention fund for the aviation industry in 2012. The frequent operational suspensions by domestic carriers suggest that the airline industry in Nigeria is ailing and requires a strategic panacea to avoid total systemic collapse. This also indicates the need for an investigation into every avenue that airlines can consider in cutting costs.

It has been advanced by many scholars that a possible strategy for organisations to remain competitive, especially in the aviation industry, is to reduce operational costs or to completely outsource such costs in some cases (Acar \& Karabulak, 2015; Babić, Kuljanin \& Kalić, 2014; Fernando, 2012; Porter, 1980). Interestingly, in a quest for a low-cost model of operation, most airline operators have focused on optimizing the functionality of their processes. For instance, Saxon and Weber (2017) advised an analysis of staff size as well as sales, distribution, and aircraft costs. Furthermore, ICAO (2017) considered only functional and productivity costs in advising lower costs for airlines. While all these views may be quite effective in cutting costs in the airline industry, this study argues that modification of customer experience could also be a viable avenue to cut costs. Such modification can be achieved by identifying the factors influencing customer experience and analyzing customer preference of such factors in order to determine how best to modify them without alienating the customer. Investigating such factors in a country like Nigeria, is justified by the high level of domestic traffic in the country (Taylor, 2015).

This research makes novel contribution to the study of strategy and organisational performance, especially from the perspective of a developing country, in three main ways. One, it identified factors of customer experience of Nigerian airline customers and evaluate the weight of each important factor based on customer preferences, using discrete choice modelling (conjoint analysis) which would be invaluable in developing a low-cost model through modification of customer experience. Airline companies may be able to reduce some of the associated overhead costs involved in their airline operation by adopting a low-cost business model and modifying some of the competitive tools, which are not overly important to the customer.

The customer standpoint is quite important because it is possible domestic airlines in Nigeria have marketing myopia, that is, they may be focused on selling air travels / services rather than meeting customers' needs (Levitt, 1960). The needs of customers and the strategies that should take care of those needs may only be obtained by analyzing data from customers themselves. Two, this study developed a low-cost model for the airline industry in the context of a developing African country, which may be replicated by airline companies in all parts of the world wishing to optimize competitive cost advantage through modification of customer experience. The model may be particularly useful to countries that have similar socio-economic realities with Nigeria. Three, to the 
best of the authors' knowledge, this may represent the first attempt to employ conjoint analysis in methodologically analyzing customers' preferences in the airline industry of an emerging economy.

The rest of the paper is structured thus: After discussing the theoretical framework, the method is discussed and results are presented. Findings are elaborated upon while implication for managers and airline organizations are discussed. It concludes with limitations and avenues for further studies.

\section{THEORETICAL FRAMEWORK}

\section{Air Travel and Low Cost Strategy}

Air travel and the aviation industry in general plays a crucial role in any nation's economic growth and contributes to gross domestic product \{GDP\} (Zhang \& Graham, 2020). The aviation industry alone contributes an average of $\$ 2.7$ trillion to world's GDP annually, which represents $3.6 \%$ of global GDP and supports jobs that are directly or indirectly related to it, as well as jobs in the hospitality and tourism industry (Aviation Benefits, 2019). In terms of contribution to global GDP, the industry is bigger than the pharmaceutical industry and the automobile manufacturing industry, which further emphasizes its importance to the global economy (Asquith, 2020). It will be expected therefore that the aviation industry in Nigeria will contribute a fair quota to the nation's GDP, however, as at 2019, only a paltry 0.14 percent was responsible for Nigeria's GDP (Punch, 2020). This may be an indication that there is a challenge with Nigeria's aviation industry.

Scholars have argued that, compared with other industries in Nigeria and Africa, the aviation industry is yet to develop or realize its full potential (Adeoye, Musa, \& Afolabi, 2018; Al-Kwifi, Frankwick \& Ahmed, 2019; Daramola \& Fagbemi, 2019; Faajir \& Zidan, 2016). It is acknowledged that the industry is facing numerous challenges. One problem that has been particularly highlighted in the recent past concerns air safety. Between 2013 and 2017, African airlines had the highest accident rate in the world (Al-Kwifi et al., 2019; IATA, 2019b), and this could have inadvertently push passengers towards other forms of transportation. Other associated problems of the aviation industry in Nigeria include: obsolete facilities; inconsistent air transportation policies (Faajir \& Zidan, 2016); and foreign exchange difficulties and lack of aircraft maintenance infrastructures (Adeoye et al., 2018).

However, a major challenge affecting the optimal performance of airlines in Nigeria has been identified as high operational costs. These costs are related to operations, infrastructure, multiple taxation, maintenance, fees and other regulatory charges (Daramola \& Fagbemi, 2019; Eze, 2019; US Embassy Report, 2012). Apart from catastrophic air crashes, according to the Airline Operators of Nigeria (AON), over 27 Nigerian airlines have failed in the last 25 years due to multiple financial taxes and levies that have hindered efficient operations and made competitiveness and survival impossible (Olawoyin, 2017). To ensure continuous operations, the remaining airlines have found a way to pass on the financial burden to passengers. In a country where the minimum wage is N30,000 $(\$ 75)$ per month and about $50 \%$ percent of the population are in extreme poverty (World Poverty, 2020); such prohibitive cost of air travel have either scared potential customers away or made actual air passengers to seek alternative means of transportation such as road or rail travel. It is therefore in light of these challenges concerning air travel in Nigeria that this study sought to examine strategies that airlines could employ to become more competitive.

There appears to be a consensus that for organisations to have sustained competitive advantage, it is important to pursue strategies that will create and sustain superior performance (Ayob \& Senik, 2015; Kovaleva \& de Vries, 2016; Porter, 1980; Porter, 1985). Porter (1980) identified three major types of strategies employed by firms to improve market positioning and stay ahead of competition. One, cost leadership strategy which suggest that firms need to strive to achieve the lowest cost of production in the industry. Two, differentiation strategy which emphasizes the ability of a firm to seek ways to differentiate its product offering from other competitors' products. Three, focus strategy which posit that organisations need to concentrate on one segment of the market instead of the whole market.

Due to the peculiarity of the aviation industry, it may be quite onerous to employ either of differentiation strategy or focus strategy. However, cost strategy may be employed to attract price 
sensitive customers and lure travelers who may be scared of road transportation, due to dilapidated road networks across major highways in Nigeria. Such cost strategy may be to discard or reduce some services offered by an airline while also reducing cost of air travel for passengers. This is known as the low cost model (Babić et al., 2014). In aviation, Low Cost Carriers started with North American airlines beginning to focus on being a business first and then as an airline around the 1980s (Diaconu, 2012). This trend later picked up in various European countries around the 1990s (Acar \& Karabulak, 2015). According to Acar and Karabulak (2015) airlines have mainly ten effective competitive tools to shape the competitive low cost strategies that they develop in deregulated markets. These low cost strategies should however be attempted with some caution in order not to completely alienate the customer as shown by Dolnicar et al. (2011).

\section{Stated Preference Theory}

Stated preference theory involves respondents' intentions or preferences for product or service based on hypothetical data. The application of stated preference approaches is concerned with eliciting responses to a predefined set of alternatives from respondents such that the alternatives are ranked, rated or chosen from (Boxall, Adamowicz, Swait, Williams \& Louviere, 1996; Johnston et al., 2017). It is popularly employed in marketing and transportation literature and are widely accepted as approaches for eliciting responses from consumers to perceptions about various attributes (Boxall et al., 1996; Hensher, 1994), especially when a new policy or new brand of product is involved and hypothetical behaviour or intention is to be examined. Unlike the revealed preference which relies on the observation of actual behaviour, the stated preference is concerned with the respondents' intentions. Stated preference therefore employs hypothetical data to estimate the ex-ante behaviour of respondents to a given service or product (Louviere \& Timmermans, 1990; Whitehead, Pattanayak, Van Houtven \& Gelso, 2008).

According to Whitehead et al. (2008), an important advantage of using stated preference approaches is the flexibility that such methods offer. This flexibility in stated preference experiments has allowed researchers in air transport industry to further analyze users' behaviour (Al Haddad, Chaniotakis, Straubinger, Plötner \& Antoniou, 2020; Nithiyanandam, Sivathanupillai, Rajendran, Jayasankar \& Muthusamy, 2020; Qin, Gao, Zhang, Chen \& Wu, 2017). Such flexibility allow researchers to construct realistic alternatives that respondents could choose from. Using the flexibility of the stated preference approach in their study, Nithiyanandam et al. (2020) established that Indian rail passengers above 60 years of age in upper class rail were likely to switch to low cost airlines. Similarly, stated preference flexibility involving respondents' preferences for service based on hypothetical data was employed by Al Haddad et al. (2020) when they examined adoption and use of urban air mobility in Munich, German. Findings showed willing respondents will prefer safety and trust, affinity to automation, and social attitude (Al Haddad et al., 2020). Thus, stated preference methods have the flexibility to estimate values for changes in many public sectors such as preferences in air transportation for which revealed preference data are either unavailable, difficult to access or predict (Johnston et al., 2017).

The contingent behaviour approach, contingent valuation method, discrete choice modelling, and conjoint analysis are common ways of testing stated preferences for a service or product using multiple hypothetical scenarios, a range of fixed alternatives and multiple choices (Abdel-Aty, Kitamura \& Jovanis, 1997; Whitehead et al., 2008). In contributing to knowledge of its usage, many scholars have employed stated preference approaches. Louviere and Timmermans (1990) reviewed its importance in leisure and recreation research, Abdel-Aty et al. (1997) used it to understand effect of advanced traffic information on choice of drivers' route, Hsiao (2009) employed it to analyse customers' preferences for physical shopping or electronic shopping while stated preference method also served Eboli and Mazzulla (2008) in measuring service quality in Italian public transportation system. Hensher (1994) opined that stated preference approach to analysis is widely accepted and used as a logical method for analyzing behavioural response in transportation and travel demand. 
It is therefore in light of the suitability of the approach to research in travel behaviour analysis that this study shall rely upon the stated preference theory to understand transportation in the air travel industry and respondents' behaviour to various competitive tools.

\section{METHODS}

The research employed a quantitative research design using the survey method to collect data from respondents and it was conducted in 2 phases. In Phase 1, the researchers extensively reviewed previous literature to identify factors considered by airline passengers as important to their air travel experience (See Appendix 1). Also, some of the competitive tools that had been altered or dropped by airlines adopting the low-cost strategy in developed countries were identified. Following Acar and Karabulak (2015), who argued about airlines having ten effective competitive tools to shape its low cost strategies in deregulated markets, the researchers selected ten competitive tools which formed a questionnaire (Questionnaire 1) which was administered to 100 customers of the airline industry who were selected using non probabilistic volunteer sampling. The aim of this was to investigate which five competitive tools were most important to airline passengers. Based on the average weighted score, five competitive tools were selected in line with their applicability while an additional service (frequent flyer programs) was selected due to its novelty within the Nigerian context. Table 1 show the selected competitive tools along with the service (attribute) levels for each service.

In Phase 2, the selected factors and their attribute levels were used to generate an orthogonal content analysis matrix. Section A of Questionnaire 2 elicited information on respondents' demographic data while the orthogonal matrix formed the basis for Section B (See Appendix 2), which was administered to 300 respondents using non-probabilistic self-selection (volunteer) sampling procedure. Prospective respondents who had travelled at least once within the Nigerian domestic airspace were asked to indicate willingness to participate in the research and data was collected from those who showed interest. This is in line with the suggestion of Saunders, Lewis and Thornhill (2007) that self-selection sampling may be appropriate where exploratory research is needed (p. 228). The study was thus limited to airline customers who had travelled by air at least once and was also limited to the competitive tools identified by respondents as being offered by airlines operating in the Nigerian aviation industry. It did not consider competitive tools offered by other airlines operating in other countries that are not necessarily offered in Nigeria. No identifying information was collected from respondents. A total of 205 copies of questionnaire were found useable and acceptable for analysis while approximately $57 \%$ of respondents frequently travelled on business trips, suggesting that a fair share of customer preferences perhaps slightly tilted towards business travelers. The resulting data was analyzed using conjoint analysis.

Table 1

Selected Competitive tools and Attribute Levels

\begin{tabular}{|c|c|c|c|c|c|c|}
\hline \multicolumn{7}{|c|}{ Attributes for selected Competitive tools } \\
\hline Service & Seat Density & $\begin{array}{l}\text { Free in-flight } \\
\text { services }\end{array}$ & $\begin{array}{l}\text { Channel of } \\
\text { ticket purchase }\end{array}$ & $\begin{array}{l}\text { Refund } \\
\text { Policy }\end{array}$ & $\begin{array}{l}\text { Limited } \\
\text { Baggage }\end{array}$ & $\begin{array}{l}\text { Frequent Flyer } \\
\text { Programme }\end{array}$ \\
\hline \multirow{3}{*}{ Attributes } & $\begin{array}{l}\text { Tight leg } \\
\text { room }\end{array}$ & $\begin{array}{l}\text { No free in- } \\
\text { flight } \\
\text { services }\end{array}$ & $\begin{array}{l}\text { Manual ticket } \\
\text { purchase }\end{array}$ & $\begin{array}{l}\text { No } \\
\text { Refund }\end{array}$ & $\begin{array}{l}\text { Paid } \\
\text { baggage }\end{array}$ & $\begin{array}{l}\text { Active Frequent } \\
\text { Flyer Reward }\end{array}$ \\
\hline & $\begin{array}{l}\text { Comfortable } \\
\text { leg room }\end{array}$ & Only drinks & $\begin{array}{l}\text { Website ticket } \\
\text { purchase }\end{array}$ & $\begin{array}{l}\text { Refund } \\
\text { allowed }\end{array}$ & $\begin{array}{l}\text { No extra } \\
\text { baggage }\end{array}$ & $\begin{array}{l}\text { No Frequent } \\
\text { Flyer Reward }\end{array}$ \\
\hline & $\begin{array}{l}\text { Extra leg } \\
\text { room }\end{array}$ & $\begin{array}{l}\text { Free in-flight } \\
\text { services }\end{array}$ & $\begin{array}{l}\text { Mobile app } \\
\text { ticket purchase }\end{array}$ & & & \\
\hline
\end{tabular}

Source: Literature review and field survey (2016) 


\section{RESULTS AND DISCUSSION}

The conjoint analysis, from table 2, show a good internal correlation between observed and estimated preferences at $1 \%$ significant level (that is, $p=0.000<0.01$ ) with a high correlation value $(\mathrm{R}$-value $=0.966)$, which suggest a good model fit. From table 3, the Cramer's V-Statistics show no significant correlations between competitive tools suggesting that there is no multi-collinearity, which is in line with findings by Upkere et al (2012). This also suggest a good model fit.

Table 2

Correlations $^{\mathrm{a}}$

\begin{tabular}{lcc}
\hline \hline & Value & Sig. \\
\hline Pearson's R & 0.966 & 0.000 \\
Kendall's tau & 0.882 & 0.000 \\
\hline \hline
\end{tabular}

a. Correlations between observed and

estimated preferences

Source: SPSS Output

Table 3

Cramer's V Statistics

\begin{tabular}{|c|c|c|c|c|c|c|}
\hline & $\begin{array}{c}\text { SEATDEN } \\
\text { TY }\end{array}$ & $\begin{array}{l}\text { CKETB } \\
\text { KING }\end{array}$ & $\begin{array}{l}\text { GHTSE } \\
\text { ICES }\end{array}$ & AGGAGE & REFUND & $\begin{array}{c}\text { FREQFLYPRO } \\
\text { GRAM }\end{array}$ \\
\hline SEATDENSITY & 1 & & & & & \\
\hline TICKETBOOKING & 0.079 & 1 & & & & \\
\hline FLIGHTSERVICES & 0.112 & 0.050 & 1 & & & \\
\hline BAGGAGE & 0.158 & 0.071 & 0.100 & 1 & & \\
\hline REFUND & 0.079 & 0.105 & 0.050 & 0.071 & 1 & \\
\hline FREQFLYPROGRAM & 0.158 & 0.071 & 0.100 & 0.100 & 0.071 & 1 \\
\hline
\end{tabular}

Factors are not all orthogonal.

Source: SPSS Output

The Importance Values show Refund as the most important to respondents with a weight of approximately $32.64 \%$ of the total competitive tools considered. This was closely followed by In-Flight Services, which accounted for about $26 \%$ of the total. However, Frequent Flyer Programs and Ticket Booking Policy were the factors that were least likely to impact the decision process when selecting an airline to fly within the domestic context. Table 4 presents importance values, as well as the rearranged importance values, of the selected competitive tools.

\section{Table 4}

Importance Values of Selected Competitive tools

\begin{tabular}{lccc} 
Importance Values & & Rearranged Importance Values (in Descending order) \\
\hline \hline SEATDENSITY & 18.273 & REFUND & 32.641 \\
TICKETBOOKING & 5.178 & FLIGHTSERVICES & 25.992 \\
FLIGHTSERVICES & 25.992 & SEATDENSITY & 18.273 \\
BAGGAGE & 12.730 & BAGGAGE & 12.730 \\
REFUND & 32.641 & FREQFLYPROGRAM & 5.186 \\
FREQFLYPROGRAM & 5.186 & TICKETBOOKING & 5.178 \\
\hline \hline
\end{tabular}

Averaged Importance Score

Source: SPSS Output

Based on the rearranged competitive tools in table 4, respondents placed much emphasis and importance on both Refund and In-Flight Services, with a combined cumulative value weight of almost $60 \%$. This suggests that as airlines in Nigeria consider low cost strategies, these two crucial factors 
must be top priority as it concerns customer value. Scholars have also opined that airline customers attach a lot of significance to refund policies, as well as in-flight services (Efthymiou, Njoya, Lo, Papatheodorou \& Randall, 2019; Jeng \& Lo, 2019; Vlachos \& Lin, 2014). In a study of international passengers at Taiwan Taoyuan International Airport, Jeng and Lo (2019) established that the depth of refund increases customer purchase intention through believability and value that low price guarantees offers. This implies that an airline with larger refunds will likely increase purchases among customers. In another study, Vlachos and Lin (2014) found that in-flight staff service serves as an attractive factor that ensures customer loyalty among Chinese business travelers in domestic flights; which infers that airlines with great in-flight experience will likely retain such passengers' loyalty.

Table 5

Path-Worth Utility Values for Selected Competitive tools

\begin{tabular}{lccc} 
Utilities & & & \\
\hline \hline & & Utility Estimate & Std. Error \\
\hline \multirow{2}{*}{ SEATDENSITY } & 1.00 & -0.574 & 0.155 \\
& 2.00 & 0.164 & 0.184 \\
TICKETBOOKING & 3.00 & 0.409 & 0.170 \\
& 1.00 & -0.056 & 0.153 \\
FLIGHTSERVICES & 2.00 & -0.111 & 0.176 \\
& 3.00 & 0.168 & 0.185 \\
BAGGAGE & 1.00 & -0.514 & 0.155 \\
& 2.00 & -0.371 & 0.187 \\
REFUND & 3.00 & 0.885 & 0.187 \\
& 1.00 & -0.342 & 0.117 \\
FREQFLYPROGRAM & 2.00 & 0.342 & 0.117 \\
(Constant) & 1.00 & -0.964 & 0.153 \\
\hline \hline
\end{tabular}

Source: SPSS Output

Table 5 presents the path-worth utilities of the selected competitive tools. Interestingly, No Refund appears to have the highest path-worth utility $(-0.964)$, however, it is pointed in a negative direction showing that customers are severely indisposed to airlines not allowing for refunds. This is quite important to consider when developing a business model as it immediately highlights a definite pitfall that should be avoided at all cost. In a research on seat allocation problem with cancellation and refund policy in airlines, Yoon, Lee and Song (2012) focused on seat allocation optimization for single flight-leg with cancellation, conducted simulations and computational experiments. It was found that full refund for full-fares class and a partial refund for discount-fares class is able to generate higher revenue performance. This is in line with the findings of this study which suggests that passengers consider refunds to be crucial. For airlines to maximize revenues, the suggestion of Yoon et al. (2012) could be implemented depending on strategic objectives.

Similarly, another factor that should be considered is the positively directed Free In-Flight Meal, which also show a high path-worth utility (0.885). This implies that respondents may definitely consider the availability of a free meal during the flight as an incentive to purchase the airline ticket. This finding is in tandem with previous works on in-flight meals and passengers' satisfaction (Han, Lee, Chua, Lee \& Kim, 2019; Zahari, Salleh, Kamaruddin, \& Kutut, 2011). In a study of general air travelers in the U.S., Han et al. (2019) confirmed that improving the overall quality of in-flight meals and beverage quality led to positive airline image and enhanced flight satisfaction. Also, in an examination of the effect of in-flight meals on satisfaction and re-flying intention levels of passengers of Malaysian Airlines, Zahari et al. (2011) found that in-flight food especially on long haul flights 
influence airline passengers' satisfaction levels. Passengers were concerned about in-flight meal attributes such as taste, freshness, appearance and choices. This suggest therefore that due to its importance to respondents, airlines in Nigeria should consider in-flight menu as part of their low cost strategies.

However, the path-worth utilities show that there is no difference between both attribute levels for Frequent Flyer Programs, which supports the earlier position that respondents may not consider this as a major factor in their decision-making. This result finds empirical support in a previous work on the service quality of major airlines in China's domestic market. Jiang and Zhang (2016) established that frequent flyer programs for either business or leisure travel have largely failed in increasing customer loyalty for the major airlines in China. One reason this may be an unimportant factor in Nigeria could be the peculiarity of the Nigerian domestic flyer usually characterized by their intention to buy the next available flight ticket rather than loyalty to brands (Ukpere et al., 2012). Another reason is that in many cases, passengers tend to be occasional or infrequent travellers, which means they cannot accumulate frequent flyer points in a short period. Also, alternative channels of transportation such as availability of road and rail transportation, which is comparatively cheaper over the same distance compared with air travel, means passengers have other cheaper options. Passengers could therefore see airline loyalty programs as unnecessary since they are not regular users.

There are several possible combinations from the output, with each combination representing a realistic option for airlines in Nigeria. However, the researchers' interest is in determining a combination from the several competitive tools and their service levels (attributes) that will achieve two things. First, the combination should have the highest total path-worth utility value, without compromising on customer preferences and services offered. Second, the combination should lead to lower costs for the airlines, which should help to reduce overhead cost if adopted. Perhaps, this would assist airline organisations to develop low-cost strategies that could ensure sustained competitive advantage and improved organisational performance.

Consideration of the path-worth utilities reveals the best business model may be one with Extra Legroom (0.409), Free In-Flight Meal (0.885), Mobile App Ticket Purchase (0.168), Free 23kg Baggage (0.342), Full Refund (0.792) and Active Frequent Flyer Reward (0.140) with a total pathworth utility of 7.880 while the worst business model appears to be Tight Legroom (-0.574), Online Booking (-0.111), No Free In-Flight Meal (-0.514), Paid Baggage (-0.342), No Refund (-0.964) and No Frequent Flyer Reward (-0.140) with a total part-worth utility of 2.469. A calculation of the mid-point between the best business model and worst business model reveal a mean path-worth utility of 5.175. To arrive at an optimal combination, any business model combination with a total path-worth utility value greater than the mean value may be considered by an airline wishing to embrace the low-cost strategy in order to reduce overhead and boost profitability. However, such optimal consideration by airlines should be ethically done, especially since customers expect organisations to be ethically responsible when deploying models to influence purchases (Hamza, Nogami \& Andrade, 2017).

\section{Implication for Managers and Airline Organisations}

Findings of this study suggest an interesting range of options for the domestic airline industry in Nigeria. Airlines wishing to cut down on their operating costs or save money on some of the competitive tools offered can consider a mix of the various attribute levels with a view to surpassing the mean path-worth utility of 5.175. The researchers in manipulating the various attribute levels have developed a workable model as follows: Partial Refund (0.172), Free In-Flight Meal (0.885), Average Seat Density (0.164), Paid Baggage (-0.342), Frequent Flyer Reward (0.140) and Mobile App Ticket Purchase (.168).

Partial refund: Respondents displayed a high preference for airlines offering Full Refund as analysis suggest this competitive tool has both the highest importance value as well as the highest path-worth utility. Although this contradicts findings by Acar and Karabulak (2015) who had identified a No Refund Policy by Pegasus Airlines employing a low cost strategy in Turkey; however, it 
is in line with findings by Efthymiou et al. (2019) and Yoon et al. (2012) that in cases of flight cancellations or delays, provision for some degree of refund, whether full or partial refund, leads to increased passenger satisfaction and revenue performance. Based on the results, the authors argue that airline companies in Nigeria could offer partial refund in order to attract more passengers and derive competitive advantage. This may initially appear expensive, however, the large number of passengers who are likely to try the airline based on the partial refund policy would increase turnover, and subsequently, profits.

Free in-flight meal: Even though some authors have found that this competitive tool is the first to be sacrificed on the altar of low cost strategy (Kousuwan, 2015; Diaconu, 2012; Murakami, 2009), however findings of this study directly contradict this assertion. Our findings suggest that passengers would appreciate some form of in-flight meals and services, which is in line with the postulations of some scholars that in-flight meals tend to influence passengers' satisfaction, and that ultimately leads to increased revenue performance (Han et al., 2019; Zahari et al., 2011). In-flight menu is just as important to passengers as the taste, appearance and freshness thereof. In consideration of the pathworth utility of in-flight menu and service, which is the second highest in this study, we suggest that airlines should maintain this competitive tool. Customer preference of airlines with free meals and drinks appear to be very high in Nigeria and a hasty change due to low cost strategy may directly affect customer loyalty.

Average seat density: This study identified seat density as an important competitive tool for airline companies. This suggest that passengers are not willing to compromise their comfort in an air travel. Acar and Karabulak (2015) posited the possibility of fitting more passengers in a flight by reducing, for instance, the seat pitch, which they defined as the distance between seats. By increasing the seat density, more tickets per flight are likely to be sold which reduces the cost per passenger ratio per flight. In line with this submission, airlines with extra leg room may consider the possibility of increasing their aircrafts' seat pitch such that an average seat density is maintained, passengers' comfort is ensured while cost per passenger ratio per flight is reduced.

Paid baggage: The findings show that passengers on domestic flights may not necessarily attach high importance to baggage. Thus, airlines may charge a premium, thereby generating extra income for those with more than the recommended hand-luggage. In addition, the airlines are likely to save baggage handling costs, as well as fuel costs arising from reduction in total weight of baggage carried per flight (Kousuwan, 2015).

Frequent flyer reward: Acar and Karabulak (2015) noted the importance of airlines considering the frequent flyer program to offer a reward program in order to balance out some of the other services that have been dropped or modified. It is expected that such incentives will further endear the brand to the customers. Interestingly, respondents in this study appeared indifferent to the frequent flyer reward. This finding is similar to the conclusion of Jiang and Zhang (2016) who posited that frequent flyer programs in China have largely failed in increasing customer loyalty for the major airlines. The indifference of respondents to airlines' frequent flyer programs may be as a result of the peculiarity of the Nigerian domestic flyer, which is usually characterized by their intention to buy the next available flight instead of showing loyalty to any particular brand (Ukpere et al., 2012). We argue that since the cost of running such a reward program is minimal, especially as consideration in rewards is through marketing communication, then it should be included in airlines' low cost strategy to attract frequent travelers.

Mobile app ticket purchase: The ability to purchase tickets using online/electronic methods has been identified to have significant effect on customer loyalty and purchase intention (Wali \& Okpara, 2012). This study extends their findings to show that customers appear to have a higher preference for purchasing tickets using mobile applications that offer increased convenience and speed of purchase. By switching to electronic ticketing, airlines can save money associated with cost of printing 
tickets, cost of confirmation and cost of airport counters. Perhaps, this could represent a major cost saving feature strategy for airlines, especially with physical airport counters. Switching to mobile app ticket purchase, for instance, could lead to cost reduction in millions of Naira paid annually by airline companies who own, maintain and operate physical airport counters. Airline companies can also reduce costs associated with passenger revenue accounting as this is greatly simplified by using electronic methods. (Doganis, 1994).

\section{Low Cost Strategy (Suggested Model)}

According to Scussel (2019), creating positive experiences for customers is at the core of the literature concerning consumers' experience. Such creations should foster business strategy formulation, which should help in developing new products and services that will improve customer experience. The authors concur with this submission in the final consideration for a proposed low strategy model for airlines. Based on respondents' preferences and analysis of the path-worth utilities therefore, the suggested model for airline companies to adopt in order to derive cost advantage and improve organisational performance is seen in the figure 1 below.

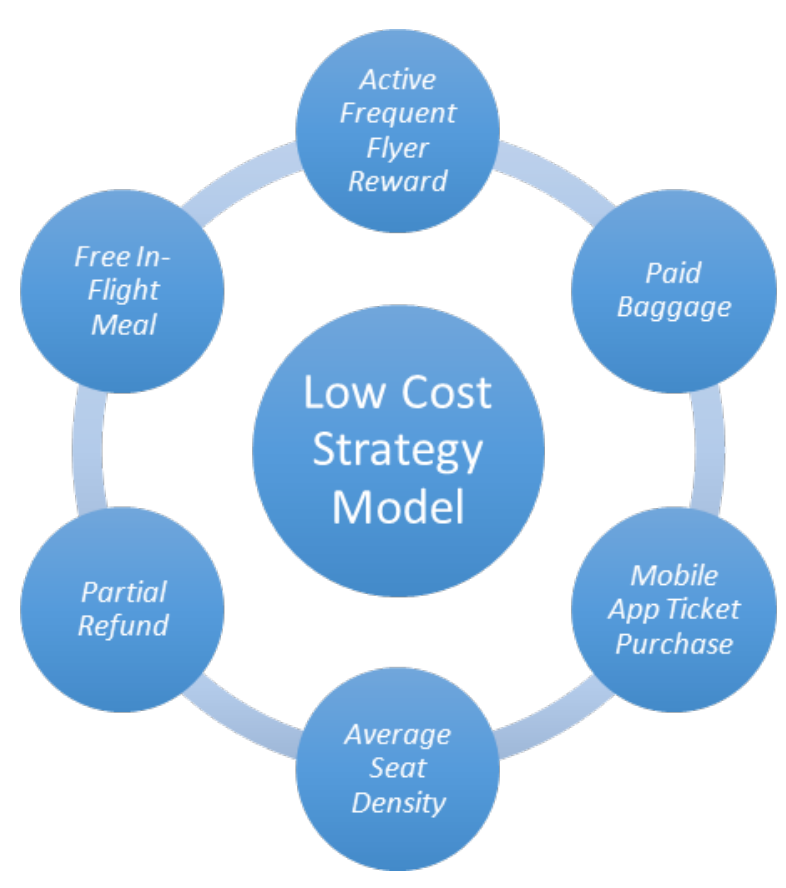

Source: Elaborated by authors

Figure 1. Model for airline companies

\section{CONCLUSION}

The purpose of this study was to develop a low cost strategy and model that airline companies in Nigeria could adopt to remain competitive. The aviation industry in the world contributes $3.6 \%$ to global GDP and supports jobs that are directly or indirectly related to it, as well as jobs in the hospitality and tourism industry. However, in Nigeria, it only contributes $0.14 \%$ to Nigeria's GDP, which infers that compared with other industries, the aviation industry is yet to develop or realize its full potential. Furthermore, there has been a steady decline in the number of domestic airlines operating in Nigeria, notwithstanding the exponential increase in average number of Nigerian air travelers. A major reason adduced for the incessant collapse of airlines in Nigeria is the enormity of their debt burden, high operational costs, financial obligation to lenders and lessors, high interest 
rates and rising fuel costs. This study therefore examined low cost strategy as a prescription for survival and profitability in the Nigerian domestic airline industry.

Low cost models have been employed in different parts of the world to attract price sensitive customers. However, airlines are advised to exercise some caution when deciding on these strategies in order not to completely alienate the customer as shown by Dolnicar et al. (2011). It therefore became imperative to analyze respondents' intentions based on the Stated preference theory, which involved respondents' preferences or intentions for an airline service premised on hypothetical data. The flexibility of stated preference experiments allowed the authors to construct realistic alternatives that respondents eventually chose from. In developing this model, factors considered as most important to Nigerian airline customers were identified and evaluated based on their respective weights, using conjoint analysis. A novelty of the study is that it provided a practical solution to the numerous challenges affecting airline operators in the Nigerian aviation industry by suggesting a practical model that could be adopted to reduce cost. Airlines' refund policy and in-flight meals were found to be very germane to the average air traveler in Nigeria while frequent flyer program had the least consideration. This study therefore developed a low cost model for the airline industry in the context of a developing African country, which allows for replication by airline companies in all parts of the world facing similar challenges.

Irrespective of interesting findings by this study, there are a few limitations which may be an avenue for further researches. One, the study focused on a single developing African country. Even though this may permit specific findings which are unique to the country's aviation industry, however, findings may not be easily generalized for other developing countries, which may have their own peculiar challenges. Since comparative multi-country analyses are absent in single-country studies, it may pave the way for future studies to consider other countries in the same study. In addition, this study only considered competitive tools identified in literature that were relatable to the Nigerian context. Further exploratory research could be conducted to identify and test other competitive tools not identified in literature.

\section{References}

Abdel-Aty, M., Kitamura, R., \& Jovanis, P. (1997). Using stated preference data for studying the effect of advanced traffic information on drivers' route choice. Transportation Research Part C: Emerging Technologies, 5(1), 39-50.

Acar A., \& Karabulak S. (2015). Competition between full service network carriers and low cost carriers in Turkish airline market. Procedia - Social and Behavioral Sciences 207, 642 - 651.

Aero Contractors (2016). http://www.flyaero.com/ (Accessed 7th September, 2016).

Adeoye, A. B., Musa, A., \& Afolabi, O. J. (2018). An evaluation of the challenges, prospect and opportunities of air transport operation in Nigeria. AFRREV STECH: An International Journal of Science and Technology, 7(2), 78-91.

Al Haddad, C., Chaniotakis, E., Straubinger, A., Plötner, K., \& Antoniou, C. (2020). Factors affecting the adoption and use of urban air mobility. Transportation Research Part A: Policy and Practice, 132, 696-712.

Al-Kwifi, O. S., Frankwick, G. L., \& Ahmed, Z. U. (2019). Achieving rapid internationalization of subSaharan African firms: Ethiopian Airlines' operations under challenging conditions. Journal of Business Research. DOI:10.1016/j.jbusres.2019.02.027.

Asquith, J. (2020, April 6). If Aviation was a country it would be the world's 20th largest by GDP. https://www.forbes.com/sites/jamesasquith/2020/04/06/if-aviation-was-a-country-it-wouldbe-the-worlds-20th-largest-by-gdp/\#6045ddc2e5b5 (Accessed 8th April, 2020).

Aviation Benefits (2019). Adding value to the economy. https://aviationbenefits.org/economicgrowth/adding-value-to-the-economy/ (Accessed $8^{\text {th }}$ April, 2020).

Ayob, A., \& Senik, Z. (2015). The role of competitive strategies on export market selection by SMEs in an emerging economy. International Journal of Business and Globalisation, 14(2), 208-225. 
Babić, D., Kuljanin, J., \& Kalić, M. (2014). Market share modeling in airline industry: An emerging market economies application. Transportation Research Procedia 3, 384 - 392.

Boxall, P., Adamowicz, W., Swait, J., Williams, M., \& Louviere, J. (1996). A comparison of stated preference methods for environmental valuation. Ecological Economics, 18(3), 243-253.

Daramola, A., \& Fagbemi, T. (2019). Air travel and airline operations in Nigeria: Market potentials and challenges. In A. Sikander (ed.), Aviation and its management - Global challenges and opportunities. DOI: 10.5772/intechopen.80646.

Diaconu, L. (2012). The evolution of the European low-cost airlines' business models: Ryanair case study. Procedia - Social and Behavioral Sciences 62, 342 - 346.

Doganis, R. (1994). The impact of liberalization on European airline strategies and operations. Journal of Air Transport Management, 1(1), 15-25.

Dolnicar, S., Grabler, K., Grün, B., \& Kulnig, A. (2011). Key drivers of airline loyalty. Tourism Management, 32, 1020 - 1026.

Eboli, L., \& Mazzulla, G. (2008). A stated preference experiment for measuring service quality in public transport. Transportation Planning and Technology, 31(5), 509-523.

Efthymiou, M., Njoya, E. T., Lo, P. L., Papatheodorou, A., \& Randall, D. (2019). The impact of delays on customers' satisfaction: An empirical analysis of the British Airways on-time performance at Heathrow Airport. Journal of Aerospace Technology and Management, 11.

Eze, C. (2019, May 17). Nigeria: Govt urged to reduce taxes, cost of aviation fuel. https://allafrica.com/stories/201905170065.html (Accessed 12th April, 2020).

Faajir, A., \& Zidan, Z. H. (2016). An analysis of the issues and challenges of transportation in Nigeria and Egypt. The Business \& Management Review, 7(2), 18-29.

Federal Airports Authority of Nigeria (2019). https://www.faan.gov.ng/harmonized-passengermovements-january-december-2018/ (Accessed 10th April, 2020).

Federal Ministry of Aviation (2014). 2014 Annual Report. Federal Republic of Nigeria.

Fernando, Y. (2012). Impact of internal marketing on operational performance: an empirical study in low cost carrier industry. Procedia - Social and Behavioral Sciences 65, 913 - 918.

Gibbons, S., \& Wu, W. (2019). Airports, access and local economic performance: Evidence from China. Journal of Economic Geography. 1-35.

Hamza, K. M., Nogami, V. K. C. \& Andrade, J. (2017). Reward and punishment from consumers towards ethical and corrupt companies: A study on price promotion and purchase intention. Consumer Behavior Review, 1(1) 38-44.

Han, H., Lee, K. S., Chua, B. L., Lee, S., \& Kim, W. (2019). Role of airline food quality, price reasonableness, image, satisfaction, and attachment in building re-flying intention. International Journal of Hospitality Management, 80, 91-100.

Hensher, D. (1994). Stated preference analysis of travel choices: The state of practice. Transportation, 21(2), 107-133.

Hsiao, M. (2009). Shopping mode choice: Physical store shopping versus e-shopping. Transportation Research Part E: Logistics and Transportation Review, 45(1), 86-95.

International Air Transport Association (2019a). The importance of air transport to Nigeria. https://www.iata.org > economic-reports > nigeria--value-of-aviation (Accessed 10th April, 2020).

International Air Transport Association (2019b). IATA releases 2018 airline safety performance. https://www.iata.org/en/pressroom/pr/2019-02-21-01/ (Accessed 10th April, 2020).

Jeng, S. P., \& Lo, M. F. (2019). Lowest price guarantees on airline websites: Perceived believability, perceived value, and purchase intentions. Journal of Air Transport Management, 75, 85-91.

Jiang, H., \& Zhang, Y. (2016). An investigation of service quality, customer satisfaction and loyalty in China's airline market. Journal of Air Transport Management, 57, 80-88.

Johnston, R. J., Boyle, K. J., Adamowicz, W., Bennett, J., Brouwer, R., Cameron, T. A., ... \& Tourangeau, R. (2017). Contemporary guidance for stated preference studies. Journal of the Association of Environmental and Resource Economists, 4(2), 319-405. 
Kovaleva, S., \& de Vries, N. (2016). Competitive strategies, perceived competition and firm performance of micro firms: The case of Trento. In D. Bögenhold, J. Bonnet, M. Dejardin \& D. de Lema (eds.), Contemporary entrepreneurship (pp. 75-93). Switzerland: Springer.

Kuosuwan, Bavornluck. (2015). Market Factors Influencing the Decision to Patronage Low Cost Carriers. Procedia - Social and Behavioral Sciences. 197. 2097-2102. 10.1016/j.sbspro.2015.07.328.

Levitt, T. (1960). Marketing myopia. Harvard Business Review, 38(4), 24-47.

Louviere, J., \& Timmermans, H. (1990). Stated preference and choice models applied to recreation research: A review. Leisure Sciences, 12(1), 9-32.

Murakami, H. (2009). Market performance of low-cost entry into the airline industry: A case of two major Japanese arkets. The Asian Journal of Shipping and Logistics, 25, 1, 103-120.

Meggison, N. (2015). Nigerian aviation industry: Challenges and prospects. Aviation roundtable seminar, Lagos.

National Bureau of Statistics (2020). Air transportation data. https://nigerianstat.gov.ng/elibrary (Accessed 8th April, 2020).

Nithiyanandam, N., Sivathanupillai, S. R., Rajendran, S., Jayasankar, S. S., \& Muthusamy, S. (2020). Impact of low cost airlines on upper class rail transport for long-haul travel in India. International Journal for Traffic and Transport Engineering, 10(1), 61-68.

Olaniyi, T. (2015). Sustainable aircraft maintenance hangar: Imperative to the Nigerian aviation industry. Computing, Information Systems, Development Informatics and Allied Research Journal, $6(1), 21-28$.

Olawoyin, 0. (2017, February 13). Why Nigerian airlines are failing - Operators. https://www.premiumtimesng.com/news/headlines/223335-nigerian-airlines-failingoperators.html (Accessed 12th April, 2020).

Porter, M. (1980). Competitive strategy: Techniques for analyzing industries and competitors. New York: Free Press.

Porter, M. (1985). Competitive advantage: Creating and sustaining superior performance. New York: The Free Press.

Punch (2020). Aviation industry contributed $0.14 \%$ to GDP in 2019 - NBS. https://punchng.com/aviation-industry-contributed-0-14-to-gdp-in-2019-nbs/ (Accessed 9th April, 2020).

Qin, H., Gao, J., Zhang, G., Chen, Y., \& Wu, S. (2017). Nested logit model formation to analyze airport parking behavior based on stated preference survey studies. Journal of Air Transport Management, 58, 164-175.

Saunders, M., Lewis, P., \& Thornhill, A. (2007). Research methods for business students (4th ed.). Essex, UK: Pearson Education Limited.

Saxon, S., \& Weber, M. (2017). A better approach to airline costs. Retrieved from https://www.mckinsey.com/industries/travel-transport-and-logistics/our-insights/a-betterapproach-to-airline-costs. Accessed on April 05, 2020.

Scussel, F. B. C. (2019). Is consumer experience the next best thing? Reflections from a systematic review and research agenda proposition. Consumer Behavior Review, 3(2), 57-69.

Taylor, A. (2015, December 4). Nigeria's air passengers traffic to hit $22 \mathrm{~m}$ by 2018. Today. Retrieved from: https://www.today.ng (Accessed 26th May, 2016).

This Day (2016, September 14). Arik airline resumes operations after temporary suspension. This Day online, Retrieved from http://www.thisdaylive.com/index.php/2016/09/14/arik-airlineresumes-operations-after-temporary-suspension/ (Accessed 16th September, 2016).

Tomováa, A. \& Ramajová, L. (2014). 2013 Frequent flyer programs and low-cost airlines: Ongoing hybridization? Procedia - Social and Behavioral Sciences. 110, 787 - 795

Uhuegho K., Olaniyi T., \& Nwokocha F. (2014). Effects of economic regulations on domestic airlines in developing countries: A case study of Nigeria. International Conference on Science, Technology, Education, Arts, Management and Social Sciences iSTEAMS Research Nexus Conference, Afe Babalola University, Ado-Ekiti, Nigeria. 
Ukpere W., Stephens M., Ikeogu C., Ibe, C., \& Akpan, E. (2012). Determinants of Airline choice-making: the Nigerian perspective. African Journal of Business Management 6(15), 5442-5455.

United States Embassy (2012). Aviation fact sheet, Economic Section Report, [Online], Available at: nigeria.usembassy.gov/nigeriafactsheet.html (Accessed: 10th March, 2016).

Vanguard (2016, September 1). Breaking: Another airline, First Nation suspends operations. Vanguard online, Retrieved from http://www.vanguardngr.com/2016/09/breaking-another-airline-firstnation-suspends-operations / (Accessed 16th September, 2016).

Vlachos, I., \& Lin, Z. (2014). Drivers of airline loyalty: Evidence from the business travelers in China. Transportation Research Part E: Logistics and Transportation Review, 71, 1-17.

Wali, A., \& Okpara, B. (2012). E-Service quality experience and customer loyalty: An emphasis of the Nigeria airline operators. European Journal of Business and Social Sciences, Vol. 1, No. 9, pp 118125

Whitehead, J., Pattanayak, S., Van Houtven, G., \& Gelso, B. (2008). Combining revealed and stated preference data to estimate the nonmarket value of ecological services: An assessment of the state of the science. Journal of Economic Surveys, 22(5), 872-908.

World Poverty (2020). https://worldpoverty.io/map (Accessed 13th April, 2020).

Yoon, M. G., Lee, H. Y., \& Song, Y. S. (2012). Linear approximation approach for a stochastic seat allocation problem with cancellation \& refund policy in airlines. Journal of Air Transport Management, 23, 41-46.

Zahari, M., Salleh, N. K., Kamaruddin, M. S. Y., \& Kutut, M. Z. (2011). In-flight meals, passengers' level of satisfaction and re-flying intention. World Academy of Science, Engineering and Technology, 60(12), 1353-1360.

Zhang, F., \& Graham, D. J. (2020). Air transport and economic growth: A review of the impact mechanism and causal relationships. Transport Reviews, 1-23. 


\section{APPENDIX}

Appendix 1: Identified Competitive Tools

\begin{tabular}{|c|c|c|c|c|c|c|}
\hline \multicolumn{7}{|c|}{ Services Identified from Literature } \\
\hline Author & $\begin{array}{l}\text { Acar \& Karabulak } \\
(2015)\end{array}$ & $\begin{array}{l}\text { Babic et al } \\
(2014)\end{array}$ & Diaconu (2012) & Kuosuwan (2015) & Murakami (2009) & $\begin{array}{l}\text { Tomova \& } \\
\text { Ramajova } \\
(2014)\end{array}$ \\
\hline \multirow{11}{*}{ Services Identified } & Price & $\begin{array}{l}\text { Point-to-Point } \\
\text { Network }\end{array}$ & $\begin{array}{l}\text { Short } \\
\text { Turnaround time }\end{array}$ & Price & Seating Class & $\begin{array}{l}\text { Frequest Plyer } \\
\text { Programs }\end{array}$ \\
\hline & Frequecy of Flight & & Free in-flight food & $\begin{array}{l}\text { Channel of ticket } \\
\text { purchase* }\end{array}$ & Price & \\
\hline & Network Policy & & Aircraft Type & Promotions & Aircraft Type & \\
\hline & Mergers \& Alliances & & $\begin{array}{l}\text { Free in-flight } \\
\text { services* }\end{array}$ & $\begin{array}{l}\text { Free in-flight } \\
\text { services }\end{array}$ & $\begin{array}{l}\text { Frequest Plyer } \\
\text { Programs }\end{array}$ & \\
\hline & Use of Travel Agencies & & Outsourcing & VIP Lounge & $\begin{array}{l}\text { Channel of ticket } \\
\text { purchase }\end{array}$ & \\
\hline & $\begin{array}{l}\text { Frequest Plyer } \\
\text { Programs }\end{array}$ & & & Refund Policy* & $\begin{array}{l}\text { Free in-flight } \\
\text { services }\end{array}$ & \\
\hline & $\begin{array}{l}\text { Human Resource } \\
\text { Innovation }\end{array}$ & & & Network Policy & $\begin{array}{l}\text { Mergers \& } \\
\text { Alliances }\end{array}$ & \\
\hline & Service Quality & & & $\begin{array}{l}\text { Use of Secondary } \\
\text { Airports }\end{array}$ & $\begin{array}{l}\text { Use of Secondary } \\
\text { Airports }\end{array}$ & \\
\hline & Seat Density* & & & Limited Baggage* & & \\
\hline & Inflight Catering & & & & & \\
\hline & $\begin{array}{l}\text { Online Registration of } \\
\text { Extra Baggage }\end{array}$ & & & & & \\
\hline
\end{tabular}

* Selected Services 
Appendix 2: Orthogonal Array of Competitive Tools and their respective attributes

Customer Preference

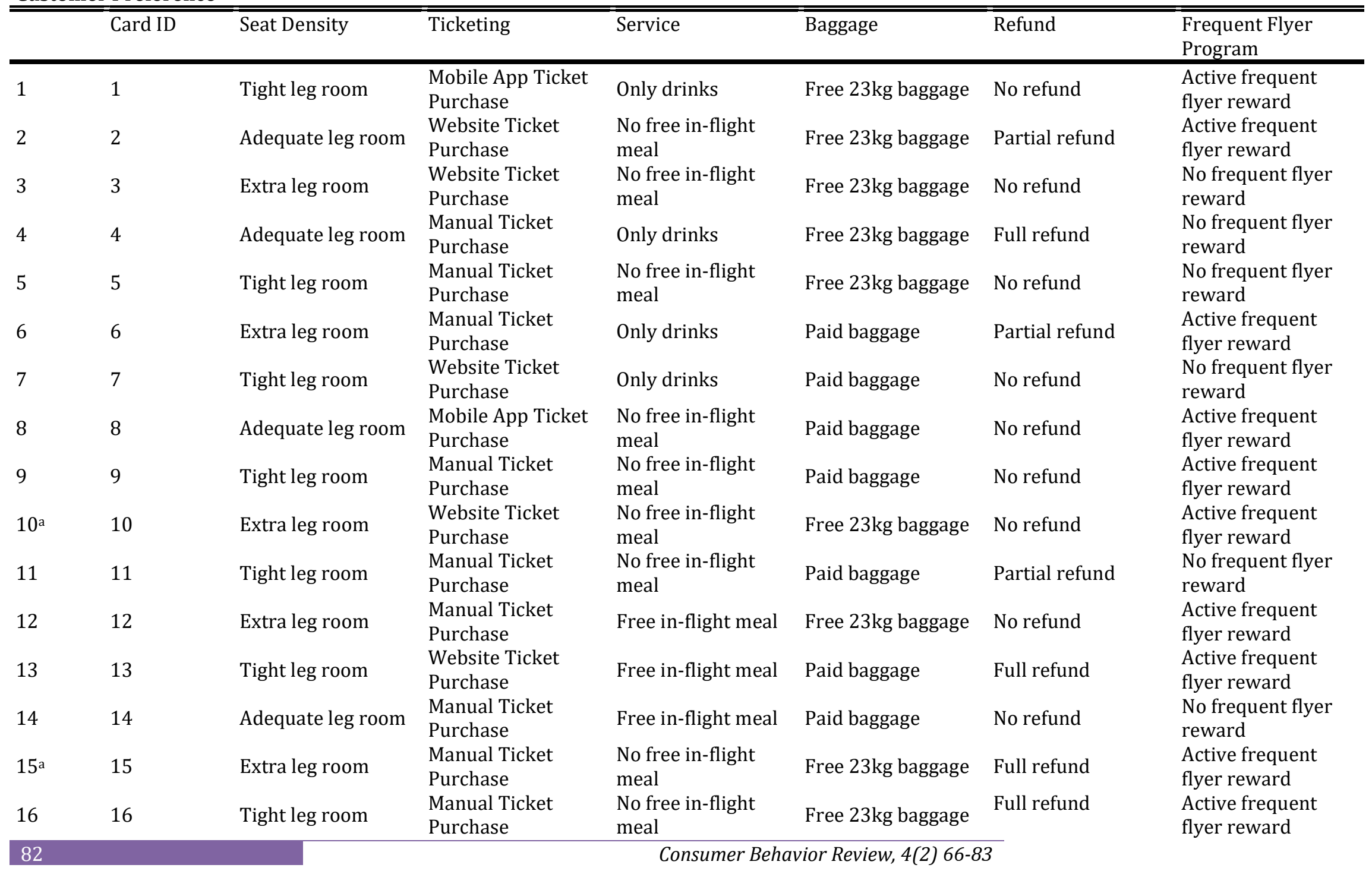




\begin{tabular}{|c|c|c|c|c|c|c|c|}
\hline 17 & 17 & Extra leg room & $\begin{array}{l}\text { Mobile App Ticket } \\
\text { Purchase }\end{array}$ & $\begin{array}{l}\text { No free in-flight } \\
\text { meal }\end{array}$ & Paid baggage & Full refund & $\begin{array}{l}\text { No frequent flyer } \\
\text { reward }\end{array}$ \\
\hline 18 & 18 & Tight leg room & $\begin{array}{l}\text { Mobile App Ticket } \\
\text { Purchase }\end{array}$ & Free in-flight meal & Free $23 \mathrm{~kg}$ baggage & Partial refund & $\begin{array}{l}\text { No frequent flyer } \\
\text { reward }\end{array}$ \\
\hline
\end{tabular}

